\title{
One fits all?
}

\section{Resilience as a Multipurpose Concept in Regional and Environmental Development}

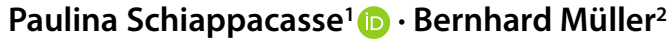

Received: 20 April 2017 / Accepted: 16 January 2018 / Published online: 29 January 2018

๑) Springer-Verlag GmbH Deutschland, ein Teil von Springer Nature 2018

\begin{abstract}
Resilience ranks high on the environmentally oriented research agenda on sustainable urban and regional development. The annual "Global Forum on Urban Resilience and Adaptation" has become a meeting point for academia and practice. The United Nations 2030 Agenda for Sustainable Development uses the term in two of their 17 Sustainable Development Goals, i.e., in Goal No. 9 on infrastructure as a basis for economic development and No. 11 on cities and human settlements. Moreover, resilience has become a prominent topic in the New Urban Agenda. Against this background, the article provides an overview of recent discussion on resilience. It scrutinizes how the concept has been used by different researchers from diverse disciplines with special reference to urban, regional and environmental studies. A systematic literature review on resilience was carried out in order to shed light on recent developments of thought and practice. All in all, 650 articles were reviewed. Following an introduction into the topic and description of the applied methodological approach, different facets of the debate on resilience are presented, and conclusions are drawn. It can be seen that the discussion of resilience needs more specificity, transdisciplinary approaches, and regional contextualization, especially in urban and regional development studies in the countries of the global south.
\end{abstract}

Keywords Resilience $\cdot$ Literature review $\cdot$ Regional development $\cdot$ Sustainable development goals

Dr. Paulina Schiappacasse

paulina.schiappacasse@tu-dresden.de

Prof. Dr. Bernhard Müller

b.mueller@ioer.de

1 Professur für Raumentwicklung, Technische Universität

Dresden, August-Bebel-Straße 30, 01219 Dresden, Germany

2 Leibniz-Institut für ökologische Raumentwicklung, Weberplatz 1, 01217 Dresden, Germany 


\section{“One fits all?”}

Resilienz als vielseitiges Konzept in der Raum- und Umweltentwicklung

\section{Zusammenfassung}

Resilienz ist zu einem Schlüsselbegriff in umweltorientierten Studien zur nachhaltigen Stadt- und Regionalentwicklung geworden. Das jährlich stattfindende „Global Forum on Urban Resilience and Adaptation“ ist inzwischen zu einer wichtigen Plattform von Wissenschaft und Praxis geworden. Die Agenda 2030 der Vereinten Nationen für nachhaltige Entwicklung benutzt den Resilienzbegriff bei zwei der 17 Nachhaltigkeitszielen: in Ziel 9 zum Aufbau einer belastbaren Infrastruktur als Basis für eine nachhaltige wirtschaftliche Entwicklung und in Ziel 11 zur nachhaltigen Entwicklung von Städten und Gemeinden. Darüber hinaus spielt Resilienz auch in der Neuen Urbanen Agenda eine große Rolle. Vor diesem Hintergrund gibt der Beitrag einen Überblick über die jüngere Diskussion zum Thema Resilienz. Er untersucht, wie das Resilienzkonzept von verschiedenen Wissenschaftlern aus unterschiedlichen Disziplinen verwendet worden ist. Dabei wird Studien zur Stadt-, Regional- und Umweltentwicklung eine besondere Beachtung geschenkt. Grundlage der Arbeit ist eine systematische Literaturanalyse, bei der 650 Artikel inhaltlich ausgewertet wurden. Nach einer Einführung in das Thema und einer Erläuterung des methodischen Ansatzes der Studie werden unterschiedliche Facetten der Resilienzdiskussion und Schlussfolgerungen für die zukünftige Arbeit gezogen. Dabei zeigt sich, dass die Diskussion in Zukunft spezifischer geführt werden sollte. Sie braucht mehr Transdisziplinarität. Und sie benötigt eine stärkere ,regionale` Kontextualisierung, insbesondere in Bezug auf Studien zur Stadt- und Regionalentwicklung in den Ländern des Globalen Südens.

Schlüsselwörter Resilienz $\cdot$ Literaturüberblick $\cdot$ Regionalentwicklung $\cdot$ Nachhaltigkeitsziele

\section{Resilience - More than Adapting to Climate Change}

In 2010, ICLEI - Local Governments for Sustainability, the World Mayors Council on Climate Change ${ }^{1}$, and the City of Bonn, Germany, made an important move to put the term "resilience" on the global urban agenda when the "Resilient Cities 2010" congress brought local government leaders and climate adaptation experts from all over the world together. Mayors from 19 countries confirmed their commitment to globally coordinated local climate action.

This first "World Congress on Cities and Adaptation to Climate Change" and the following annual "Resilient Cities" congresses which, in 2012, were renamed as "Global Forum on Urban Resilience and Adaptation", were (and are) extremely useful for raising the awareness of academia and practice for disturbances and shocks that threaten urban development, especially those related to the consequences of climate change. However, the initial focus on climate change also contributed to a somewhat narrow interpretation of the term "resilience" in urban-regional and environmental studies. Meanwhile, a broader understanding has emerged. The more recent "Resilient Cities" congresses have considerably widened the scope of topics discussed.

Moreover, the 2030 Agenda for Sustainable Development of 2015, and the New Urban Agenda, adopted by the Habitat III conference in Quito and issued by the United Nations General Assembly in 2016, link resilience mainly with

\footnotetext{
1 See http://www.iclei.org (07.12.2017).
}

disaster risk reduction strategies in general. Although there is still strong reference to climate change adaptation, more issues have appeared on the agenda. Within this framework, for example, Birkmann/Welle/Solecki et al. (2016: $605 \mathrm{ff}$.) request more attention be paid to protection for urban areas, i.e. especially small and mid-sized cities, from extreme events.

Although the term "resilience" has only rather recently been acknowledged as a key concept of the international development agenda, it has a much longer history as a keyword in practice and academia. Hall (2018), in his recent Scopus based, bibliometric analysis, traces the use of the term back to the time before the 1960s. Whereas before 1960 "resilience" was mentioned only 51 times in journal article titles, abstracts or keywords, this increased to almost 51,000 until 2016 . About $70 \%$ of the scientific articles making a reference to resilience were published between 2000 and 2014 , only about $7 \%$ before this period. The situation in social and environmental sciences, the two fields on Hall's list which are closest to urban-regional and environmental studies, is similar: resilience was referred to in almost 11,000 and more than 9,000 articles respectively, of which in both cases almost 70\% appeared between 2000 and 2014 .

During this period, "resilience" not only became increasingly popular, but it was also often used as a one-fitsall concept in urban and regional development discourses. Davoudi (2012: 299) pointed out that "there is a growing number of governmental and non-governmental reports which aim to develop ready-made, off-the-shelf toolkits for resilience-building" although "it is not quite clear what resilience means, beyond the simple assumption that it is good 
to be resilient". The positive notion attributed to resilience has also been criticized as demonstrating a certain powerblindness as we have to consider that more resilience "for some people or places may lead to the loss of resilience for others" (Davoudi 2012: 306). In society, bouncing-back to a former state or achieving a new equilibrium, resilience may simply stabilize prevailing interests and existing power structures. And transforming a system by enhancing its adaptive capacities may bring about new winners and losers. Nevertheless, in times of crisis, resilience is at the centre of many policy discussions. Resilience has been "deployed by a wide range of decision-makers, policy communities and non-state actors" (Shaw 2012: 308). For Raco and Street (2012: 1065), it has even become a "key area of political debate". Resilience ideas are also increasingly powerful in academia. Some scholars even see resilience as a legitimate substitute for the concept of sustainability because the approach aims to handle a system's development while preventing it from collapse, or in other words: securing it to sustain (Fiksel 2003; Zolli 2013).

However, the term "resilience" is also highly contested as being fuzzy, glittery, and slippery. Some authors refer to it being used as a mere buzz- or catchword without concrete meaning (Bodin/Wiman 2004; Swanstrom 2008; Comfort/Boin/Demchak 2010; Pendall/Foster/Cowell 2010; Müller 2011; Davoudi 2012; Reghezza-Zitt/Rufat/DjamentTran et al. 2012; Brown 2014). Critics target its lack of conceptual clarity, difficulties in operationalizing it, and the lack of supporting empirical evidence (Pike/Dawley/ Tomaney 2010; Simmie/Martin 2010; Walker/Cooper 2011; Bourbeau 2013). Thus, it seems that resilience is used with a variety of meanings, e.g. referring to sustainability, vulnerability and governance (Reghezza-Zitt/Rufat/DjamentTran et al. 2012).

Against this background, the aim of this article is to scrutinize how the concept of resilience has been used and adopted by different researchers from diverse disciplines with special reference to urban, regional and environmental studies. A systematic literature review on resilience was carried out in order to shed light on recent developments of thought and practice.

Following this introductory section, the paper is organized as follows. Section 2 explains the methodological approach of the study. Section 3 gives an overview of the debate about resilience based on the results of our analysis. And finally, the paper draws conclusions for research and practice in Section 4.

\section{Methodology - Choosing Journals and Publications for Analysis}

The methodological approach of this study consists of four steps. In the first step, 209 peer-reviewed journals, published in the English language, were selected and classified in order to identify relevant publications on resilience. All journals are related to urban and regional as well as social, political and environmental studies. A draft list of journals was elaborated and discussed within the framework of the doctoral programme of the Dresden Leibniz Graduate School (DLGS) ${ }^{2}$ which focused during this time on different issues of urban and regional resilience. All participants in the exercise were well advanced in their literature analyses.

In the second step, a keyword-based search for the term "resilience" was conducted. It covered scientific articles which were published between 2000 and 2013, i.e. a period of major discussion about resilience (Hall 2018: 21). The search criteria were that the term "resilience", or more specifically "resilien*", had to be contained in the title and/or in the set of keywords of an article, and that the publications were easily accessible in order to be able to make a relevant contribution to the scientific discussion. A set of available electronic databases, such as The Business Source Premier (EBSCO), Emerald Management eJournals, Management \& Organization Studies (CSA), SpringerLink, Taylor \& Francis Online, Wiley Online Library, ESA Journals, SAGE Journals, Cambridge Journals Online (CJO), and ScienceDirect (Elsevier) was used to identify the respective papers. After a review of retrieved articles and a relevance check, 650 of them were selected for further analysis (see Table 1).

In the third step, a Microsoft Access database was constructed in order to ensure that the retrieved papers (records) could be managed effectively and efficiently. Creating the database of references allowed information to be shared, and duplicated references to be easily identified and deleted.

Finally, in the fourth step, 650 articles were analyzed using a taxonomy for classifying literature. The taxonomy and the formulated questions helped in assessing reviews by translating abstract criteria into concrete applicable categories (Cooper 1988). For this purpose, the taxonomy was structured using a set of six main categories supported by a number of questions (Table 2). Moreover, the authors' affiliation was scrutinized in order to identify inter-connections between articles and the way the concept of resilience was used.

\footnotetext{
2 This paper was originally elaborated as a contribution to the structured doctoral programme of the Dresden Leibniz Graduate School, a joint venture project between the Leibniz-Institut für ökologische Raumentwicklung (IÖR) and the Technische Universität Dresden.
} 
Table 1 Peer reviewed journals and articles obtained using the search term "resilien*" either in the article's title and/or among the set of keywords

\begin{tabular}{|c|c|c|}
\hline Journal & Articles & $\begin{array}{l}\text { Analyzed } \\
\text { Articles }\end{array}$ \\
\hline AMBIO & 16 & 16 \\
\hline Annual Review of Ecology and Systematic & 7 & 7 \\
\hline $\begin{array}{l}\text { Annual Review of Environment and Re- } \\
\text { sources }\end{array}$ & 7 & 7 \\
\hline Applied Geography & 6 & 5 \\
\hline $\begin{array}{l}\text { Cambridge Journal of Regions, Economy } \\
\text { and Society }\end{array}$ & 11 & 11 \\
\hline $\begin{array}{l}\text { Cities - The International Journal of Urban } \\
\text { Policy and Planning }\end{array}$ & 8 & 8 \\
\hline Conservation Biology & 16 & 15 \\
\hline Disasters & 17 & 17 \\
\hline Ecological applications & 23 & 23 \\
\hline Ecological economics & 33 & 33 \\
\hline Ecological Management \& Restoration & 7 & 7 \\
\hline Ecological modelling & 31 & 31 \\
\hline Ecology & 19 & 19 \\
\hline Ecology and Society & 157 & 157 \\
\hline Ecology letters & 25 & 25 \\
\hline Ecosystems & 15 & 15 \\
\hline Environment \& Urbanisation & 11 & 11 \\
\hline Environment and Development Economics & 4 & 4 \\
\hline Environmental Conservation & 8 & 8 \\
\hline Environmental Management & 23 & 23 \\
\hline Environmental Science and Policy & 14 & 14 \\
\hline Forest Ecology and Management & 17 & 15 \\
\hline Global Environmental Change & 46 & 46 \\
\hline $\begin{array}{l}\text { International Journal of Disaster Resilience } \\
\text { in the Built Environment }\end{array}$ & 17 & 17 \\
\hline Journal of Cleaner Production & 7 & 7 \\
\hline Journal of Disaster Risk Studies & 5 & 5 \\
\hline Journal of Environmental Management & 15 & 15 \\
\hline Land Use Policy & 6 & 6 \\
\hline $\begin{array}{l}\text { Local Environment: The international Jour- } \\
\text { nal of Justice and Sustainability }\end{array}$ & 13 & 3 \\
\hline Natural Hazards & 50 & 6 \\
\hline Oecologia & 7 & 6 \\
\hline Politics & 9 & 9 \\
\hline $\begin{array}{l}\text { Proceedings of the National Academy of } \\
\text { Sciences USA }\end{array}$ & 12 & 12 \\
\hline Progress in Human Geography & 4 & 4 \\
\hline Raumforschung und Raumordnung & 8 & 8 \\
\hline $\begin{array}{l}\text { Resilience. International Policies, Dis- } \\
\text { courses and Practices }\end{array}$ & 15 & 5 \\
\hline Science & 7 & 7 \\
\hline Social Indicators Research & 4 & 4 \\
\hline Trends in Ecology and Evolution & 7 & 7 \\
\hline Urban Studies & 12 & 12 \\
\hline Other Journals & 267 & 0 \\
\hline Total & 986 & 650 \\
\hline
\end{tabular}

Table 2 Taxonomy for the analysis of articles on resilience

Categories/Questions
Definition: What kind of definition of "resilience" does the study
provide?
Research method: In which way does the study deal with the opera-
tionalization of resilience?
Research focus: Which research focus does the study have?
Research design: Which type of research design does the study em-
ploy?
Subject: To which issue is the study related
(resilience of what)?
Object: To which problem is the study related
(resilience to what)?

With this methodological approach we ensure that

1. there is no bias in the way articles were chosen,

2. major scientific articles on resilience from the indicated time period that are contained in the abovementioned databases and were influential in the scientific discussion are included in the analysis, and

3. all steps in the selection process are transparent and reproducible.

However, this methodological approach also causes certain limitations. It is important to note that the purpose of this literature review is to analyze how the concept of resilience is being applied by different scholars. Thus, the analysis is influenced by our interpretation of the papers' contents. Furthermore, authors can only review what is found in a paper, and therefore, even before the analysis, a certain element of publication bias may be present. It has also to be recognized that the choice of other databases for keyword research might have led to a different array of publications, and implied additional or different findings. Finally, papers which were published before, during and after the period of analysis and which were not referred to in this review might have had an effect on the findings.

\section{Shaping Resilience - A Multifaceted Discussion in Scientific Literature}

\subsection{Nodes and Networks - Dominant Resilience Discussion Circles}

Resilience is a concept that cuts across disciplines. The concept originated in material sciences and engineering, mainly to refer to the capacity of materials and physical structures to withstand stress. It expanded rapidly to other fields, such as medicine and psychology, and environmental sciences, and later computer sciences and informatics, social sciences and other fields (Hall 2018). Within urban, regional and environmental studies, a lively debate has emerged over the 
past decades. In the following, we analyze by whom and how the discussion was shaped.

Analysis of the affiliation of authors of the articles contained in the sample used shows that during the first decade of the 2000s influential nodes of the international resilience discussion have evolved, i.e. hubs where the debate about and dominant notions of resilience have been shaped. Such hubs are mainly found in three world regions: 260 authors of articles were affiliated to institutions in North America, 193 to institutions in Europe, and 84 to institutions in Australia. Scholars from universities in African, Latin-American and Asian countries played a comparatively minor role although some of them had some influence through their affiliation with international scientific networks of (university) research centres which dedicate much of their work to the study of resilience. The majority of scientific papers on resilience, i.e. 212 out of 650 or one-third of all articles under review, was elaborated by researchers from institutions in the United States. Scholars from the United Kingdom and Australia follow on the next two ranks with $13 \%$ each.

Most of the authors are somehow linked with the Resilience Alliance, an important research network which consists of 17 nodes, recognized as a "Scientific and Intellectual Social Movement" (SIM) by Parker and Hackett (2012: 22). The Alliance is described as a "series of concentric rings extending from its most influential member out to peripheral researchers" (Parker/Hackett 2012: 26). Members of the Resilience Alliance pay an annual fee to support the network's operations and journal, "Ecology and Society". Moreover, they are linked with several influential international research centres, including the Stockholm Resilience Centre, the Centre of Excellence for Coral Reef Studies and the South American Institute for Resilience and Sustainability Studies (Parker/Hackett 2012: 27). The alliance, its major centres and the respective journal seem to provide the basis for what has been called the "institutionalization of resilience thinking" (Brown 2014: 109) which influences both the academic field and policy making.

Three institutions account for almost $10 \%$ of all publications on resilience during the period under review: the University of Stockholm which is home to the Stockholm Resilience Centre, established in 2007; the Australian Commonwealth Scientific and Industrial Research Organisation; and Arizona State University which is the base of the Global Institute for Sustainability. These organizations are at the same time important nodes of the Resilience Alliance.

The reasons why there are more publications on resilience in some countries and specific institutions than in others may be linked to issues like funding of research facilities, incentives, brain gain, language, publication opportunities and/or scientific networking. Additionally the "discursive dominance" (Christmann/Ibert/Kilper et al. 2012: 18) of the members of the Resilience Alliance in the aca- demic field can be mentioned here. However, it is far beyond the scope of this article to fully explain why some organizations dominate the discussion on resilience more than others.

Whereas the presence and dominance of scientific institutions from certain countries is easily understandable, the low profile of universities and researchers from other parts of the world is obscure. Resilience is high on the policy agendas of many governments and donors who increasingly see the importance of tackling fragility, poverty, vulnerability to conflicts, as well as disasters and uncertainties in general by enhancing the resilience of communities and livelihoods (Global Humanitarian Assistance 2013), especially in less developed countries. Therefore, the evident lack of scholars from Latin American, African and Asian institutions in the resilience debate is difficult to explain. This is even more the case as the concept of resilience needs to be "regionally" contextualized, and it is mainly scholars from the different regional realities who are familiar with the histories, cultures, and planning and legal frameworks of their countries, and therefore could be expected to make important and more specific contributions to the debate.

The gap in the scientific literature has started to be narrowed down by "grey literature" on resilience which is produced by government agencies, think tanks, and environmental groups, often together with local researchers and research institutions. Such publications provide accessible and evidence-based information for better understanding, promoting and enhancing resilience (Schiappacasse/Müller 2013). The practical, application-oriented focus of such publications, which are often written in the local language, can considerably help to shape local debates and decisiontaking. However, there are also less favourable implications as regards their scientific value and their accessibility due to limited awareness of their existence and language barriers.

Additionally, as resilience is a sensitive topic for many international agencies, there is a tendency to undertake single-agency discussions and evaluations, and to facilitate joint learning processes only under the given political conditions of a country. Thus, local scholars may see the application of scientific methodology and/or academic rigor in the elaboration of studies as less urgent and valuable than knowledge transfer. All this makes it difficult for researchers and research institutions from developing countries to influence or even enter the international scientific debate on resilience.

\subsection{Defining Resilience - Arenas of Contestation and Fuzziness}

There is little consensus as to how the term "resilience" should be defined, conceptualized and applied in different contexts. Although many entry points to the discussion 
Table 3 Results of the analysis of articles on resilience

\begin{tabular}{|c|c|c|}
\hline Categories/Questions & Characteristics & Total $(\%)$ \\
\hline $\begin{array}{l}\text { Definition: What kind of definition of "resilience" } \\
\text { does the study provide? }\end{array}$ & $\begin{array}{l}\text { Own } \\
\text { Quoted } \\
\text { Not provided } \\
\text { Not applicable }\end{array}$ & $\begin{array}{l}34(5.2) \\
350(53.8) \\
245(37.7) \\
21(3.2)\end{array}$ \\
\hline $\begin{array}{l}\text { Research method: In which way does the study deal } \\
\text { with the operationalization of resilience? }\end{array}$ & $\begin{array}{l}\text { Reflective } \\
\text { Quantitative methods } \\
\text { Qualitative methods } \\
\text { Mixed methods } \\
\text { Surrogate } \\
\text { Literature review }\end{array}$ & $\begin{array}{l}254(39.1) \\
102(15.7) \\
105(16.2) \\
73(11.2) \\
92(14.2) \\
24(3.7)\end{array}$ \\
\hline $\begin{array}{l}\text { Research focus: Which research focus does the } \\
\text { study have? }\end{array}$ & $\begin{array}{l}\text { Conceptual } \\
\text { Operational } \\
\text { Implementation }\end{array}$ & $\begin{array}{l}429(66.0) \\
207(31.8) \\
14(2.2)\end{array}$ \\
\hline $\begin{array}{l}\text { Research design: Which type of research design } \\
\text { does the study employ? }\end{array}$ & $\begin{array}{l}\text { Case study } \\
\text { Multiple cases study } \\
\text { Theoretical paper }\end{array}$ & $\begin{array}{l}259(39.8) \\
135(20.8) \\
256(39.4)\end{array}$ \\
\hline $\begin{array}{l}\text { Subject: To which issue is the study related } \\
\text { (resilience of what)? }\end{array}$ & $\begin{array}{l}\text { Economy } \\
\text { Physical infrastructure } \\
\text { Ecosystems } \\
\text { Communities } \\
\text { Institutions (planning/ } \\
\text { management) } \\
\text { Cities and regions } \\
\text { Companies/Organizations } \\
\text { Policy Instruments } \\
\text { Multiple } \\
\text { Unclear } \\
\text { Not applicable }\end{array}$ & $\begin{array}{l}34(5.2) \\
14(2.2) \\
250(38.5) \\
96(14.8) \\
39(6.0) \\
9(1.4) \\
8(1.2) \\
10(1.5) \\
11(1.7) \\
55(8.5) \\
124(19.1)\end{array}$ \\
\hline $\begin{array}{l}\text { Object: Which problem is the study related to } \\
\text { (resilience to what)? }\end{array}$ & $\begin{array}{l}\text { Security problems } \\
\text { Natural events } \\
\text { Economic crisis } \\
\text { Social and political threats } \\
\text { Anthropogenic threats } \\
\text { Biological dangers } \\
\text { Multiple threats } \\
\text { Unclear } \\
\text { Not applicable }\end{array}$ & $\begin{array}{l}12(1.8) \\
164(25.2) \\
16(2.5) \\
6(0.9) \\
96(14.7) \\
10(1.5) \\
145(22.3) \\
77(11.8) \\
124(19.0)\end{array}$ \\
\hline
\end{tabular}

exist, three major interpretations of resilience can be recognized which are relevant for urban-regional and environmental studies (Folke 2006; Davoudi 2012; Seeliger/Turok 2013):

a) In engineering sciences, resilience is interpreted as the capability to bounce-back. This is related to a single equilibrium understanding.

b) In ecology, resilience is associated with the capacity to absorb shocks, and self-repair. This is related to a multiple equilibria understanding.

c) In social-ecological studies, resilience is understood as the capacity for continual adaptation.

This is one of the reasons why Davoudi (2012: 302) with reference to Scheffer (2009) proposes using the term "evolutionary resilience" for this approach.

However, this does not mean that resilience is always explicitly defined and operationalized. On the contrary, defining and operationalizing resilience seem to have be- come arenas of "fuzziness" over the last decade, although there is no shortage in literature of attempts to analyze the meaning of resilience (Gunderson 2000; Folke 2006; Manyena 2006; Brand/Jax 2007; Bahadur/Ibrahim/Tanner 2010; Maru 2010; Simmie/Martin 2010; Zhou/Wang/Wan et al. 2010; Martin-Breen/Anderies 2011; Strunz 2011; Alexander 2013, among others). Authors elaborate categories of resilience, trace the history of the concept, and look into its potential application in explaining the longterm development of urban and regional economies.

In our study we scrutinize how explicitly the term "resilience" is defined and operationalized in the set of papers under review, and what notions of resilience these papers relate to. The results of our analysis show (Table 3) that the majority of papers refer to definitions elaborated by a limited number of authors. And a large number of articles did not provide a definition at all: 350 papers (53.8\%) quote a definition of resilience published by others, 34 (5.2\%) provide their own definition, and 245 (37.7\%) do not include 
any definition, while in 21 articles (3.2\%) a single definition is not provided as the papers' objective is to present, compare or analyze different definitions of resilience.

The fact that in a large number of papers the concept of resilience is neither explicitly clarified nor operationalized might be interpreted as an indication that during the past decade it has become increasingly "trendy" to use the word resilience in publications. This may also have contributed to the general notion that there is a lack of precision regarding what resilience is all about, which interests it is linked with, and which strategic options it offers.

With respect to the most cited definitions of resilience it is interesting to note:

1. the strong influence of Holling's (1973) definition from environmental science and regional studies;

2. the hegemony of the ecological and social-ecological understanding of resilience;

3 . the understanding of resilience as a system state and process; and

4. the emergence of new definitions based on earlier concepts.

In the following, these four aspects will be explained in more detail.

1. The influence of Holling: More than three decades after the publication of Holling's seminal paper, his definition continues to dominate the discussion. Perhaps one of the reasons behind this preponderance is related to Alexander's findings about the etymology of resilience: although the word "resilience" has a long history, "many students of the robustness of people, objects and systems believe that 'resilience' was coined by Holling in his landmark 1973 paper" (Alexander 2013: 2708). Examples of this conceptual understanding were also found in this analysis, e.g. regarding the publications of Gunderson (2000: 425), Beermann (2011: 836), Lintz, Wirth and Harfst (2012: 363), Kärrholm, Nylund and Prieto de la Fuente (2014: 121). Although Holling was not the first to use the term resilience, the frequency of articles quoting his paper clearly shows that he brought resilience to prominence in the debate on sustainability. Holling's definition has been accepted by many researchers, and nowadays it seems central to the social-ecological understanding of "resilience" as a concept.

2. Hegemony: Most cited definitions do not differ considerably from Holling's (1973) proposal. They are connected to the concept of ecological and/or social-ecological resilience. Thus, "multiple meanings" of resilience, as mentioned by Brand and Jax (2007: 23), were hardly observed. Adger's definition (2000) is the only one of the most cited papers that targets social resilience during the study period. Adger's aim was to investigate whether and how social resilience is distinct from ecological resilience, and how valid it is to integrate social and ecological dimensions. Furthermore, the most cited authors are members or collaborators of the Resilience Alliance, reflecting how this coalition's discourse has gained acceptance within the wider scholarly community. The hegemony of the understanding of resilience may be one of the reasons why the three characteristics of resilience, first introduced by Carpenter, Walker, Anderies et al. (2001) as influential members of the network, are clearly seen among the most cited definitions:

a) the magnitude (amount) of a disturbance (change) relative to a threshold that can be absorbed (buffer) before a system changes its structure;

b) the ability (degree) at which a system can recover after a disturbance, and

c) the capacity to learn from, and to create, new things from disturbance (change).

3. State and process: None of the prevailing definitions consider resilience as a mere result, i.e. the capacity to "bounce back" based on a single equilibrium. In contrast, the dominating understanding includes resilience as both a state and a process. Resilience as a state refers to resilience as an inherent element or the ability of a system to react at the moment of the shock: "resilience preexists the impact, it is a potential revealed through the impact" (Reghezza-Zitt/Rufat/Djament-Tran et al. 2012: 2). Resilience as a process refers to resilience in terms of continual learning and taking responsibility for making more informed decisions to improve and adapt the capacity to handle uncertainties.

4. Emerging new definitions: The analysis of further definitions of resilience (Cutter/Barnes/Berry et al. 2008: 599; Hudson 2010: 22; Treado 2010: 106; Lalonde 2011: 457; Biggs/Schlüter/Biggs et al. 2012: 423; Ali/Jones 2013: 10, Lucini 2013: 62; Zhu/Ruth 2013: 74; Kärrholm/Nylund/Prieto de la Fuente 2014: 121) reveals the strong influence of the ecological meaning of resilience as an analogy used to understand how communities, regions and enterprises prepare for environmental change, react, and adapt, organize and learn. Such definitions show that authors recall earlier explanations for defining resilience. However, this transfer to the social realm is viewed as problematic by many authors (Davoudi 2012; Cote/Nightingale 2012; Brown 2014). For example, whereas ecological systems are power neutral, power is a central issue in social systems. Natural conditions are much easier to model than complex socio-political and socio-economic structures and processes. Additionally, understanding society through the "lens of ecology", might lead us to "lose the insights from critical social science" (Davoudi 2012: 306). Regardless of whether the transfer of concepts from ecology to social sciences 
is appropriate or not, there is no doubt that ecologists from the Resilience Alliance made a significant innovation and contribution when they started to use adaptive management in resilience studies.

\subsection{Tailored Versus Universal Resilience - Resilience of what and to what?}

Shocks and uncertainties are present at various scales, and they have various time horizons. Often they have interlinked impacts, e.g., regarding economic, environmental, political and social dimensions. Given this complexity, resilience studies require a holistic perspective and a clear identification of the involved variables to allow the phenomenon to be satisfactorily captured.

Taking this up, one may make a distinction between tailored and universal resilience. Both imply an important operational difference in understanding and choosing management strategies. Tailored resilience, in the literature also referred to as "specified resilience", arises in response to the questions: resilience of what, and to what? (Carpenter/ Walker/Anderies et al. 2001; Lebel/Anderies/Campbell et al. 2006). It defines on the one hand the part of a system that might cross a certain threshold (resilience of what), and, on the other hand, it refers to the kinds of shocks a system has to tolerate (resilience to what).

In contrast, universal resilience, in the literature also referred to as "general resilience", concerns the resilience of every aspect of a system coping with uncertainty in all ways (expected and/or novel). Universal resilience is related to studies which tackle multiple issues, and follow a broader approach. As regards the "of what" part of the question, there are only 11 studies following a universal resilience approach (1.7\% of the sample), whereas regarding the "to what" part of the question there are 145 cases dealing with multiple risks, representing $22.3 \%$ of the sample.

Thus, the majority of studies are related to tailored resilience. As regards the "of what" part of the abovementioned question, the most common objects of studies on resilience are ecosystems (38.5\%). Researchers mainly focus on understanding how much disturbance an ecosystem can handle. In the investigation, coral reefs are the ecosystems researched most often, as they are declining worldwide due to a variety of anthropogenic influences. The resilience of communities $(14.8 \%)$ has only lately emerged as an object of study, targeting such scattered subjects as rural groups, neighbourhoods, ancient civilizations, the elderly and livelihoods.

It is worth underscoring that these studies focus more on recovery from stresses than on adaptation or change. A number of studies $(6.0 \%)$ emphasize how institutional and governance structures contribute to increased resilience.
The analysis and evaluation of the institutional view of disaster (pre/during/post event) predominate, as institutions are challenged to improve the effectiveness of their strategies (Kendra/Wachtendorf 2003; Tompkins 2005; Frazier/ Wood/Yarnal 2010). In this category attention is drawn to an emerging literature stressing the importance of indigenous knowledge as a component of institutional resilience (Trosper 2002; Abidi-Habib/Lawrence 2007; Baral/Stern/ Heinen 2010).

The response of economic systems to a long period of disturbance, or a rapid change, attracts scholarly attention $(5.2 \%)$. This is especially true regarding the reaction of agro-systems to economic disturbances, such as the wine industry (Nicholas/Durham 2012), dairy farming (Van Apeldoorn/Kok/Sonneveld et al. 2011), organic farming (Milestad/Hadatsch 2003), and irrigation (Luers 2005). Also the impact on farmers and their livelihoods is discussed (Schouten/Opdam/Polman et al. 2013). The results of our analysis also show a novel interest in analyzing normative and indicative frameworks beyond disaster, including climate change strategies and environmental policies (Roberts 2010; Benson/Garmestani 2011; Manyena/ Mavhura/Muzenda et al. 2013).

Reviewed papers with a "social object of research" account for less than $30 \%$. This reflects, first, the difficulties of transferring knowledge from the study of ecological systems to the social realm. Second, most of these papers (70\%) focus on tailored resilience, e.g. on a particular domain. Third, a substantial number of articles $(8.5 \%)$ do not define the part of the system that might cross a threshold, thus contributing to the imprecise use of the concept of resilience.

Resilience needs a reference, i.e., one must clarify which type of uncertainties can push or affect the system or subsystem causing it to perhaps cross a threshold ("resilience to what"). Uncertainties, or shocks, can be defined as disturbances that cause disruption in a system. They can be classified according to various considerations:

a) Duration: Shocks may occur over minutes, months or decades. Foster (2006) distinguishes between "sudden shocks" and "slow burns" which are often found in regions undergoing economic, social or political transformation like a heavily industrialized region shifting its economic base to services or biotechnology.

b) Frequency: An event might affect a city or region regularly (e.g. floods or seasonal fluctuation in employment), frequently (e.g. extreme weather events or forest fires) or rarely (e.g. economic crises).

c) Predictability: This relates to the extent to which events can be anticipated or not, or to whether the occurrence has high probability and low risk or low probability and high risk. 
d) Origin of the uncertainty, e.g., natural events, security and economic threats.

e) Scale of impact: Disturbances vary in their impacts regarding spatial scale, from household and local levels to macro and global scales.

Results show that shocks are mainly considered as risks threatening an existing system. Accordingly, studies of the effects of natural events, mainly disasters, dominate the discussion (25\%). The unprecedented frequency and cost of natural disasters and the projected increase of their severity due to climate change create significant challenges and new risks for cities and their vulnerable populations. In particular, research on climate change attracts most attention (explicitly mentioned in 79 articles). The impact of natural events is often exacerbated by unsustainable development activities like deforestation, overfishing, overgrazing, land use changes and urban sprawl.

Anthropogenic threats provide the second-most common motivation for investigation among researchers (15\%). Here the idea is to emphasize studies stressing the importance of institutions, legal instruments and planning frameworks as mechanisms that integrate the human and ecological spheres (Hanna 2008). For instance, Green, Cosens, Garmestani (2013) and Green, Garmestani, Van Rijswick et al. (2013) argue that a number of legal and planning regimes might be "ill-suited" for dealing with resource management because they are designed around an outdated conception of social-ecological dynamics. Much of the environmental legislation currently in place was developed around the scientific understanding prevalent in the 1970s that the natural world existed within an "envelope" of predictability (Garmestani/Allen/Benson 2013; Garmestani/Benson 2013).

In short, natural events attract much more attention than slow-paced anthropogenic, economic, social and political stresses. Despite the considerable influence that resilience might have regarding social, political and security threats, there are still relatively few empirically grounded contributions to this area (Table 3). Perhaps the methodological complexities of isolating economic, political and social "variables", or simply the lack of appropriate data, explain the limited number of studies on these topics.

\subsection{Research Focus and Design - Conceptual Clarity and Practical Relevance}

One of the most widespread criticisms regarding resilience is related to the lack of conceptual clarity (Brand/Jax 2007; Pike/Dawley/Tomaney 2010; Bourbeau 2013; Joseph 2013). For instance, Reghezza-Zitt, Rufat, Djament-Tran et al. (2012: 1) mention that "the abundant use of the concept, especially in social sciences, does not always come with a solid theoretical base". In order to determine whether these critiques are justified both the research design and the focus of the sample of papers have been scrutinized (Table 3).

With respect to the research focus, conceptual papers dominate the sample (66\%). Two-fifths of the articles $(40.0 \%)$ are based on theoretical considerations (e.g., panarchy, the adaptive cycle). The other half of conceptual papers is split between those taking individual (33.8\%) and multiple (18.2\%) case studies as a basis for developing a conceptual contribution. Regarding the research design, about $40 \%$ of the reviewed sample papers are theoretical articles about resilience, about $40 \%$ are single case studies, and only $20 \%$ look at multiple cases. It is not surprising that $80 \%$ of the theoretically oriented papers have a conceptual focus. However, it may be surprising that the vast majority of single and multiple case studies also have a conceptual focus. In contrast, papers which are clearly implementation oriented represent a minority: about $30 \%$ in the first and only $2.2 \%$ in the second case (Table 3 ).

These results suggest that there is an abundance of theoretical contributions and ample empirical evidence (case studies) oriented towards systematizing resilience capacity. The main topics under theoretical discussion are:

a) the relationship between resilience and other concepts like vulnerability, sustainable development, adaptation capacity and/or governance,

b) the contribution of resilience thinking (Walker/Salt 2006)

to specific disciplines or objects of study, and

c) the potential or limitations of the concept's application.

Conceptual contributions to the understanding of resilience have increased during the last decade. This conceptual development has benefited from increasing collaboration with geographers, archaeologists, political scientists and environmental lawyers.

Various definitions of resilience enter the domain of operationalization of resilience as they include terms like "measure of", "amount of", "degree to which" and "magnitude of". Thus, it is meaningful to analyze papers oriented towards discussing operational issues; these make up a total of $31.8 \%$ of the sample (Table 3 ). The operationalization of resilience shows a high correlation with issues of context and perspective, as more than $75 \%$ of operational papers are based on single or multiple case studies. This reflects the increased success of the concept in stimulating applied research in different fields.

Among the reviewed papers, resilience is defined, transferred and operationalized, but recommendations are only very rarely made concerning how resilience could be promoted or enhanced. Implementation and practice-oriented papers $(2.2 \%)$ are mainly contributions to strengthening the 
capacity of local bodies to integrate disaster risk reduction into development.

Although promoting resilience is a growing area of interest in practice, in the scientific arena the discourse is still largely theoretical and epistemological. However, one cannot disregard individual strategic contributions, such as the book published by Walker and Salt (2012) and the "grey literature" produced by international organizations (UNISDR 2012; UNISDR 2013; ACP-EU 2013), governmental agencies (Mayor of London 2011), consultancy-oriented organizations (Grosvenor 2014) and think tanks (Resilience Alliance 2010; The Rockefeller Foundation/Arup 2014).

As already mentioned above, linking science and practice in the resilience domain is not an easy task. Resilience is subject to a spectrum of interpretations (e.g. from returning to a single, stable equilibrium to wholesale reorganization or renewal) among researchers. But in practice, resilience remains frequently understood along the lines of "recovery" (Sperling/Valdivia/Quiroz et al. 2008). Despite increased attention toward resilience as a management framework, questions remain as to how to apply resilience in everyday management decisions (Carpenter/Walker/Anderies 2001; Folke et al., 2010).

\subsection{Methodological Challenges - From Reflection to Practical Application}

There is a strong bias towards reflective methods in dealing with resilience. Reflective methods are employed in almost $40 \%$ of the reviewed studies (Table 3 ). In their papers, many researchers present arguments on a series of explicit or implicit questions without providing systematic empirical evidence. This may be partly due to the fact that operationalizing resilience is connected with a number of practical challenges (Carpenter/Westley/Turner 2005). Challenges related, for example, to determining which variables to measure, developing standard metrics (Cutter/ Barnes/Berry et al. 2008), making resilience observable (Nyström/Graham/Lokrantz et al. 2008; Robinson/Berkes 2010), locating and finding measures for thresholds (Eakin/ Luers 2006), acquiring sufficient data (Malone/Brenkert 2008), and measuring resilience in a context of multiple fast and slow-moving drivers of change (Nelson/Adger/ Brown 2007).

Resilience research incorporates methods from both natural and social sciences, including theoretical deduction, mathematical models, network analyses, literature analyses, experiments, surveys, ethnographic approaches, interviews, questionnaires and archaeological techniques, among others. Papers in which qualitative $(16.2 \%)$ and quantitative (15.7\%) methods are employed for operationalization make up about one-third of all reviewed journal articles on resilience, neither perspective being clearly dominant.
Furthermore, $14.2 \%$ of the papers follow a "surrogate" approach, including the use of more than one method of data collection or analysis, thus allowing an understanding of resilience appropriate to its complexity and dynamism (Table 2). Following Carpenter, Westley and Turner (2005), the word "surrogate" is used here in order to acknowledge that direct measurements of resilience may not be possible, and that it may be necessary to infer information through the use of models (Bennett/Cumming/Peterson 2005).

Finally, a mixed-method approach combining reflection, qualitative and quantitative data, as well as steps for interpreting data, is used in about $11 \%$ of the articles (Table 3 ). This provides the necessary contextualization that metrics alone cannot fully capture.

In summary, no common and universally accepted methodologies exist to assess the reactions of systems to shocks and uncertainties. This result is not entirely surprising, as resilience is essentially about context and perspective, and each case requires a tailored methodological approach. There is a difference between building resilience, for example, among deprived communities in Latin America, and measures claiming to enhance resilience capabilities among communities in Southern Asian regions, e.g. as part of poverty-reduction oriented state building programmes.

However, the rapid uptake of the concept of resilience by development cooperation agencies and foundations has intensified discussions about the implementation and facilitation of resilience-building measures. And this has challenged the research community to make a leap from theory to practice, and to metrics. As a result, a methodological approach providing a framework that includes different steps is becoming more common to the analysis and management of the inherent capacity of systems to produce resilience.

For instance, Walker, Carpenter, Anderies et al. (2002) propose a four-step framework for analyzing social and ecological resilience, and to make resilience operational. In the first step, they refer to the subject of resilience (resilience of what), for example stakeholder groups or individual ecosystem services. In the second step, the focus is on the object of resilience (resilience to what). Which related problems and challenges threaten the abovementioned system? Which scenarios exist in order to enhance the robustness of models in formulating responses to unexpected events? In the third step, possible driver variables (interconnectivity, norms and social capital) are identified, as are the processes in the system that govern the dynamics of those very variables (innovation, institutional support and learning capacity). Finally, the fourth step is dedicated to resilience management. The framework includes describing the boundaries of the system, framing key issues, and identifying critical thresholds. 


\section{Conclusions}

Resilience has become a catchword in academia, practice and policy making. Many questions have been raised regarding its conceptual and methodological clarity. The fact that the United Nations use the term in two of the 17 Sustainable Development Goals makes it even more timely and important to have an up-to-date look at its background, notion, emergence and use. The results of a systematic literature review and the in-depth scrutiny of 650 papers published on resilience between 2000 and 2013, a period which was decisive for shaping the discussion in environmental urban and regional studies, allow us to draw a number of conclusions.

The bulk of literature which has been developed over the past decade is impressive. There is an abundance of theoretical contributions and ample empirical evidence oriented towards systematizing resilience. Here, natural events have drawn much more attention than slow-paced anthropogenic, economic, social or political stresses. This is at least partially due to the strong influence of the Resilience Alliance, a powerful global network of research institutions dedicated to studies on resilience.

There is a hegemony of the ecological and social-ecological understanding of resilience. Ecosystems are the most intensively studied objects of resilience studies. This reflects the dominance of the ecological perspective in the interpretation of resilience. Papers regarding urban and regional studies with a "social object of research" are not as common. This may be due to the difficulties of transferring ideas from the ecological system to the social realm.

The majority of papers under review referred to definitions elaborated by a rather limited number of authors. We found Holling's (1973) definition on understanding resilience in environmental sciences and regional studies to have a strong influence; even recently emerged "new" definitions are still mainly based on earlier concepts.

Papers that focus on defining the concept of resilience dominate. Almost half of the papers are based on theoretical considerations, while the other half use individual or multiple case studies as bases for developing a conceptual contribution. Thus, notions of resilience ideas are being increasingly confronted with case studies to assess their capacity and their contribution to policy development.

Nevertheless, there is a large number of studies that do not provide clear definitions of resilience or use primarily reflective methodological approaches. This fact may have been one of the reasons why the concept has been greatly criticized for its vagueness. However, as we could see here, the concept of resilience is not vague or fuzzy at all.

In terms of uncertainties, research on climate change has attracted most attention. The unprecedented frequency and cost of natural disasters and the projected increase of their severity due to climate change create challenges and new risks for cities and regions. However, there is research evidence of a social turn in resilience applied to city regions. This strongly contributes to making resilience a wellgrounded and multipurpose concept suitable to be more often and systematically applied in regional studies.

No straightforward methodological application of resilience seems to exist, probably due to the multidisciplinary and multipurpose nature of the concept. Resilience research incorporates quantitative and qualitative methods, including deductive approaches, mathematical models, network analysis, literature analysis, ethnography, interviews and questionnaires, among others.

Scholars from institutions in Latin America, Africa and Asia have made far fewer contributions on understanding resilience than authors from North America, Europe or Australia. This is rather striking as the concept needs to be "regionally" contextualized. This is especially important as resilience has now become a keyword in the new international sustainable development agenda for the coming decades. Thus, the further increase in resilience studies and a regionalization of its meaning and application in regional development are to be expected and are viewed as necessary.

Against the background of these results and the fact that "resilience" has become a key term in academic research and international development policy, we see the need for further development in two directions:

Transdisciplinary research: There is a vast body of scientific literature about resilience in urban-regional and environmental studies, and there is immense practice-based knowledge about how to deal with sudden shocks and slow burns under different conditions in different parts of the world. What still needs to be intensified is the dialogue and joint production of knowledge, bringing together research and practice in a structured way. Such transdisciplinary work needs to be based on real world experience, i.e. concrete cases, on the one hand, and a clear theoretical and conceptual understanding of resilience on the other hand.

Regional contextualization: Researchers from vulnerable and shock-prone regions of the world should play a more explicit role in the resilience discussion as resilience needs to be understood against the background of the individual legal, politico-administrative and planning framework of a country, and to take into consideration the individual and collective livelihoods and aspirations of the people. However, the further strengthening of such regionally based research will not emerge by itself, it needs a facilitating framework. The annual "Global Forum on Urban Resilience and Adaptation" is a cornerstone to promote such research. Also, the Sustainable Development Goals and the New Urban Agenda play a role here. However, there 
seems also to be a need for national governments to take a more active role, especially in the "global south" where they could help to establish more conducive research frameworks. Such work has to be locally relevant and globally embedded, theory based and with an impact on application, as well as being expert driven and people oriented at the same time. The successful creation of the Center for Sustainable Urban Development (CEDEUS) ${ }^{3}$ in Chile can be taken as a good practice example which deserves repetition in other countries.

\section{References}

Abidi-Habib, M.; Lawrence, A. (2007): Revolt and remember: How the Shimshal Nature Trust develops and sustains social-ecological resilience in northern Pakistan. In: Ecology and Society 12, 2, 35.

ACP-EU - Africa Caribbean Pacific - European Union (2013): Agricultural resilience in the face of crisis and shocks. Brussels. = Brussels Rural Development Briefings 30.

Adger, W.N. (2000): Social and ecological resilience: Are they related? In: Progress in Human Geography 24, 3, 347-364. https://doi.org/ $10.1191 / 030913200701540465$

Alexander, D.E. (2013): Resilience and disaster risk reduction: an etymological journey. In: Natural Hazards and Earth System Sciences 13, 11, 2707-2716. https://doi.org/10.5194/nhess-13-27072013

Ali, F.M.M.; Jones, K. (2013): Negotiating community resilience in the city in a time of political change and deficit reduction. In: International Journal of Disaster Resilience in the Built Environment 4, 1, 9-22. https://doi.org/10.1108/17595901311298973

Bahadur, A.V.; Ibrahim, M.; Tanner, T. (2010): The resilience renaissance? Unpacking of resilience for tackling climate change and disasters. Brighton. $=$ Strengthening Climate Resilience Discussion Paper 1.

Baral, N.; Stern, M.J.; Heinen, J.T. (2010): Growth, collapse, and reorganization of the Annapurna Conservation Area, Nepal: An analysis of institutional resilience. In: Ecology and Society 15, 3, 10.

Beermann, M. (2011): Linking corporate climate adaptation strategies with resilience thinking. In: Journal of Cleaner Production 19, 8, 836-842. https://doi.org/10.1016/j.jclepro.2010.10.017

Bennett, E.M.; Cumming, G.S.; Peterson, G.D. (2005): A systems model approach to determining resilience surrogates for case studies. In: Ecosystems 8, 8, 945-957. https://doi.org/10.1007/ s10021-005-0141-3

Benson, M.H.; Garmestani, A.S. (2011): Embracing panarchy, building resilience and integrating adaptive management through a rebirth of the National Environmental Policy Act. In: Journal of Environmental Management 92, 5, 1420-1427. https://doi.org/10.1016/j. jenvman.2010.10.011

Biggs, R.; Schlüter, M.; Biggs, D.; Bohensky, E.L.; Burnsilver, S.; Cundill, G.; Dakos, V.; Daw, T.M.; Evans, L.S.; Kotschy, K.; Leitch, A.M.; Meek, C.; Quinlan, A.; Raudsepp-Hearne, C.; Robards, M.D.; Schoon, M.L.; Schultz, L.; West, P.C. (2012): Toward principles for enhancing the resilience of ecosystem services. In: Annual Review of Environment and Resources 37, 421448. https://doi.org/10.1146/annurev-environ-051211-123836

Birkmann, J.; Welle, T.; Solecki, W.; Lwasa, S.; Garschagen, M. (2016): Boost resilience of small and mid-sized cities. In: Nature 537, 7622, 605-608. https://doi.org/10.1038/537605a

\footnotetext{
3 www.cedeus.cl (11.12.2017).
}

Bodin, P.; Wiman, B. (2004): Resilience and other stability concepts in ecology: Notes on their origin, validity, and usefulness. In: The ESS Bulletin 2, 2, 33-43.

Bourbeau, P. (2013): Resiliencism: Premises and promises in securitisation research. In: Resilience: International Policies, Practices and Discourses 1, 1, 3-17. https://doi.org/10.1080/21693293. 2013.765738

Brand, F.S.; Jax, K. (2007). Focusing the meaning(s) of resilience: resilience as a descriptive concept and a boundary object. In: Ecology and Society 12, 1, 23.

Brown, K. (2014): Global environmental change I: A social turn for resilience? In: Progress in Human Geography 38, 1, 107-117. https://doi.org/10.1177/0309132513498837

Carpenter, S.R.; Westley, F.; Turner, M.G. (2005): Surrogates for resilience of social-ecological Systems. In: Ecosystems 8, 8, 941944. https://doi.org/10.1007/s10021-005-0170-y

Carpenter, S.; Walker, B.; Anderies, J.M.; Abel, N. (2001): From metaphor to measurement: resilience of what to what? In: Ecosystems 4, 8, 765-781. https://doi.org/10.1007/s10021-001-0045-9

Christmann, G.; Ibert, O.; Kilper, H.; Moss, T. (2012): Vulnerability and resilience from a socio-spatial perspective. Towards a theoretical framework. Erkner. = IRS Working Paper 45.

Comfort, L.K.; Boin, A.; Demchak, C.C. (eds.) (2010): Designing Resilience: Preparing for Extreme Events. Pittsburgh.

Cooper, H.M. (1988): Organizing knowledge syntheses: A taxonomy of literature reviews. In: Knowledge in Society 1, 104-126. https:// doi.org/10.1007/BF03177550

Cote, M.; Nightingale, A.J. (2012): Resilience thinking meets social theory: situating social change in socio-ecological systems (SES) research. In: Progress in Human Geography 36, 4, 475-489. https://doi.org/10.1177/0309132511425708

Cutter, S.L.; Barnes, L.; Berry, M.; Burton, C.; Evans, E.; Tate, E.; Webb, J. (2008): A place-based model for understanding community resilience to natural disasters. In: Global Environmental Change 18, 4, 598-606. https://doi.org/10.1016/j.gloenvcha.2008. 07.013

Davoudi, S. (2012): Resilience: A Bridging Concept or a Dead End? In: Planning Theory and Practice 13, 2, 299-307. https://doi.org/ $10.1080 / 14649357.2012 .677124$

Eakin, H.; Luers, A.L. (2006): Assessing the vulnerability of socialenvironmental systems. In: Annual Review of Environment and Resources 31, 365-394. https://doi.org/10.1146/annurev.energy. 30.050504 .144352

Fiksel, J. (2003): Designing Resilient, Sustainable Systems. In: Environmental Science and Technology 37, 23, 5330-5339. https://doi. org/10.1021/es0344819

Folke, C. (2006): Resilience: The emergence of a perspective for social-ecological systems analyses. In: Global Environmental Change 16, 3, 253-267. https://doi.org/10.1016/j.gloenvcha.2006. 04.002

Folke, C.; Carpenter, S.R.; Walker, B.; Scheffer, M.; Chapin, T.; Rockström, J. (2010): Resilience thinking: integrating resilience, adaptability and transformability. In: Ecology and Society 15, 4, 20.

Foster, K.A. (2006): A case study approach to understanding regional resilience. Berkeley. = Working Paper 2007-08. Institute of Urban and Regional Development, University of California.

Frazier, T.G.; Wood, N.; Yarnal, B. (2010): Stakeholder perspectives on land-use strategies for adapting to climate-change-enhanced coastal hazards: Sarasota, Florida. In: Applied Geography 30, 4, 506-517. https://doi.org/10.1016/j.apgeog.2010.05.007

Garmestani, A.S.; Allen, C.R.; Benson, M.H. (2013): Can law foster social-ecological resilience? In: Ecology and Society 18, 2, 37.

Garmestani, A.S.; Benson, M.H. (2013): A framework for resiliencebased governance of social-ecological systems. In: Ecology and Society $18,1,9$.

Global Humanitarian Assistance (2013): Global Humanitarian Assistance Report 2013. Bristol. 
Green, O.O.; Cosens, B.A.; Garmestani, A.S. (2013): Resilience in transboundary water governance: the Okavango River Basin. In: Ecology and Society 18, 2, 23.

Green, O.O.; Garmestani, A.S.; Van Rijswick, H.F.M.W.; Keessen, A.M. (2013): EU water governance: Striking the right balance between regulatory flexibility and enforcement? In: Ecology and Society 18, 2, 10.

Grosvenor (2014): Resilient Cities: A Grosvenor Research Report.

Gunderson, L.H. (2000): Ecological resilience - in theory and application. In: Annual Review of Ecology and Systematics 31, 1, 425439.

Hall, C.M. (2018): Resilience in tourism: development, theory and application. In: Cheer, J.M.; Lew, A.A. (eds.): Tourism, Resilience and Sustainability. Adapting to Social, Political and Economic Change. Abingdon, New York, 18-33.

Hanna, S.S. (2008). Institutions for managing resilient salmon (Oncorhynchus spp.) ecosystems: the role of incentives and transaction costs. In: Ecology and Society 13, 2, 35.

Holling, C.S. (1973): Resilience and stability of ecological systems. In: Annual Review of Ecology and Systematics 4, 1-23. https:// doi.org/10.1146/annurev.es.04.110173.000245

Hudson, R. (2010): Resilient regions in an uncertain world: wishful thinking or a practical reality? In: Cambridge Journal of Regions, Economy and Society 3, 1, 11-25. https://doi.org/10.1093/cjres/ rsp026

Joseph, J. (2013): Resilience as embedded neoliberalism: a governmentality approach. In: Resilience: International Policies, Practices and Discourses 1, 1, 38-52. https://doi.org/10.1080/ 21693293.2013.765741

Kärrholm, M.; Nylund, K.; Prieto de la Fuente, P. (2014): Spatial resilience and urban planning. Addressing the interdependence of urban retail areas. In: Cities 36, 121-130. https://doi.org/10.1016/ j.cities.2012.10.012

Kendra, J.M.; Wachtendorf, T. (2003): Elements of resilience after the World Trade Center disaster: Reconstituting New York City's emergency operations centre. In: Disasters 27, 1, 37-53. https:// doi.org/10.1111/1467-7717.00218

Lalonde, C. (2011): Managing crises through organisational development: a conceptual framework. In: Disasters 35, 2, 443-464. https://doi.org/10.1111/j.1467-7717.2010.01223.x

Lebel, L.; Anderies, J.M.; Campbell, B.; Folke, C.; Hatfield-Dodds, S.; Hugues, T.P.; Wilson, J. (2006): Governance and the capacity to manage resilience in regional social-ecological systems. In: Ecology and Society $11,1,19$.

Lintz, G.; Wirth, P.; Harfst, J. (2012): Regional structural change and resilience. In: Raumforschung und Raumordnung 70, 4, 363-375. https://doi.org/10.1007/s13147-012-0175-x

Lucini, B. (2013): Social capital and sociological resilience in megacities context. In: International Journal of Disaster Resilience in the Built Environment 4, 1, 58-71. https://doi.org/10.1108/ 17595901311299008

Luers, A.L. (2005): The surface of vulnerability: An analytical framework for examining environmental change. In: Global Environmental Change 15, 3, 214-223. https://doi.org/10.1016/j. gloenvcha.2005.04.003

Malone, E.L.; Brenkert, A.L. (2008). Uncertainty in Resilience to Climate Change in India and Indian States. In: Climatic Change 91, 3-4, 451-476. https://doi.org/10.1007/s10584-008-9472-3

Manyena, S.B. (2006): The concept of resilience revisited. In: Disasters 30, 4, 434-450. https://doi.org/10.1111/j.0361-3666.2006.00331. $\mathrm{x}$

Manyena, S.B.; Mavhura, E.; Muzenda, C.; Mabaso, E. (2013): Disaster risk reduction legislations: Is there a move from events to processes? In: Global Environmental Change 23, 6, 1786-1794. https://doi.org/10.1016/j.gloenvcha.2013.07.027

Martin-Breen, P.; Anderies, J.M. (2011): Resilience: A Literature Review. New York.
Maru, Y.T. (2010): Resilient regions: Clarity of concepts and challenges to systemic measurement. Socio-Economics and the Environment in Discussion. Clayton South. CSIRO Working Paper Series 2010-04.

Mayor of London (2011): Managing risks and increasing resilience. The Mayor's climate change adaptation strategy. London.

Milestad, R.; Hadatsch, S. (2003): Organic farming and social-ecological resilience: the alpine valleys of Sölktäler, Austria. In: Ecology and Society $8,1,3$.

Müller, B. (2011): Urban and Regional Resilience - A New Catchword or a Consistent Concept for Research and Practice? In: Müller, B. (ed.): Urban Regional Resilience. How do Cities and Regions Deal with Change? Heidelberg, 1-13. = German Annual of Spatial Research and Policy 2010.

Nelson, D.R.; Adger, W.N.; Brown, K. (2007): Adaptation to environmental change: contributions of a resilience framework. In: Annual Review of Environment and Resources 32, 395-419. https:// doi.org/10.1146/annurev.energy.32.051807.09034

Nicholas, K.A.; Durham, W.H. (2012): Farm-scale adaptation and vulnerability to environmental stresses: Insights from winegrowing in Northern California. In: Global Environmental Change 22, 2, 483-494. https://doi.org/10.1016/j.gloenvcha.2012.01.001

Nyström, M.; Graham, N.A.J.; Lokrantz, J.; Norström, A.V. (2008): Capturing the cornerstones of coral reef resilience: linking theory to practice. In: Coral Reefs 27, 4, 795-809. https://doi.org/10. 1007/s00338-008-0426-z

Parker, J.N.; Hackett, E.J. (2012): Hot spots and hot moments in scientific collaborations and social movements. In: American Sociological Review 77, 1, 21-44. https://doi.org/10.1177/ 0003122411433763

Pendall, R.; Foster, K.A.; Cowell, M. (2010): Resilience and regions: building understanding of the metaphor. In: Cambridge Journal of Regions, Economy and Society 3, 1, 71-84. https://doi.org/10. 1093/cjres/rsp028

Pike, A.; Dawley, S.; Tomaney, J. (2010): Resilience, adaptation and adaptability. In: Cambridge Journal of Regions, Economy and Society 3, 1, 59-70. https://doi.org/10.1093/cjres/rsq001

Raco, M.; Street, E. (2012): Resilience Planning, Economic Change and the Politics of Post-recession Development in London and Hong Kong. In: Urban Studies 49, 5, 1065-1087. https://doi.org/ 10.1177/0042098011415716

Reghezza-Zitt, M.; Rufat, S.; Djament-Tran, G.; Le Blanc, A.; Lhomme, S. (2012): What resilience is not: uses and abuses. In: CyberGeo 621, 1-23. https://doi.org/10.4000/cybergeo. 25554

Resilience Alliance (2010): Assessing Resilience in Social-Ecological Systems: Workbook for Practitioners. Revised Version 2.0.

Roberts, D. (2010): Prioritizing climate change adaptation and local level resilience in Durban, South Africa. In: Environment and Urbanization 22, 2, 397-413. https://doi.org/10.1177/ 0956247810379948

Robinson, L.W.; Berkes, F. (2010): Applying resilience thinking to questions of policy for pastoralist systems: Lessons from the Gabra of Northern Kenya. In: Human Ecology 38, 3, 335-350. https://doi.org/10.1007/s10745-010-9327-1

Scheffer, M. (2009): Critical Transitions in Nature and Society. Princeton.

Schiappacasse, P.; Müller, B. (2013): Urban and Regional Resilience: A review of scientific contributions in environmental sciences (2000-2013). Internal Report. Lehrstuhl für Raumentwicklung, Technische Universität Dresden.

Schouten, M.; Opdam, P.; Polman, N.; Westerhof, E. (2013): Resilience-based governance in rural landscapes: Experiments with agro-environment schemes using a spatially explicit agent-based model. In: Land Use Policy 30, 1, 934-943. https://doi.org/10. 1016/j.landusepol.2012.06.008

Seeliger, L.; Turok, I. (2013): Towards sustainable cities: extending resilience with insights from vulnerability and transition the- 
ory. In: Sustainability 5, 5, 2108-2128. https://doi.org/10.3390/ su5052108

Shaw, K. (2012): "Reframing" resilience: Challenges for Planning Theory and Practice. In: Planning Theory and Practice 13, 2, 308333. https://doi.org/10.1080/14649357.2012.677124

Simmie, J.; Martin, R. (2010): The economic resilience of regions: towards an evolutionary approach. In: Cambridge Journal of Regions, Economy and Society 3, 1, 27-43. https://doi.org/10.1093/ cjres/rsp029

Sperling, F.; Valdivia, C.; Quiroz, R.; Valdivia, R.; Angulo, L.; Seimon, A.; Noble, I. (2008): Transitioning to Climate Resilient Development: Perspectives from Communities in Peru. Washington, DC. = Environment Department Papers 115 .

Strunz, S. (2011): Is conceptual vagueness an asset? Resilience research from the perspective of philosophy of science. Lüneburg. University of Lüneburg, Working Paper Series in Economics 205.

Swanstrom, T. (2008): Regional Resilience: A Critical Examination of the Ecological Framework. Berkeley. = Working Paper 2008-07, Institute of Urban and Regional Development. MacArthur Foundation Research Network on Building Resilience Cities. University of California

The Rockefeller Foundation; Arup (2014): City Resilience Framework - City Resilience Index. London.

Tompkins, E.L. (2005): Planning for climate change in small islands: Insights from national hurricane preparedness in the Cayman Islands. In: Global Environmental Change 15, 2, 139-149. https:// doi.org/10.1016/j.gloenvcha.2004.11.002

Treado, C.D. (2010): Pittsburgh's evolving steel legacy and the steel technology cluster. In: Cambridge Journal of Regions, Economy and Society 3, 1, 105-120. https://doi.org/10.1093/cjres/rsp027

Trosper, R.L. (2002): Northwest coast indigenous institutions that supported resilience and sustainability. In: Ecological Economics 41, $2,329-344$
UNISDR - The United Nations Office for Disaster Reduction (2012): How To Make Cities More Resilient. A Handbook for Local Government Leaders. A contribution to the global campaign 2010-2015: Making Cities Resilient - My City is Getting Ready! Geneva.

UNISDR - The United Nations Office for Disaster Reduction (2013): Making Cities Resilient: Summary for Policymakers. A global snapshot of how local governments reduce disaster risk. Geneva.

Van Apeldoorn, D.F.; Kok, K.; Sonneveld, M.P.W.; Veldkamp, T. (2011): Panarchy rules: rethinking resilience of agroecosystems, evidence from Dutch dairy-farming. In: Ecology and Society 16, 1,39 .

Walker, B.; Carpenter, S.; Anderies, J.; Abel, N.; Cumming, G.S.; Janssen, M.; Lebel, L.; Norberg, J.; Peterson, G.D.; Pritchard, R. (2002): Resilience management in social-ecological systems: A working hypothesis for a participatory approach. In: Ecology and Society $6,1,14$.

Walker, J.; Cooper, M. (2011): Genealogies of resilience: From systems ecology to the political economy of crisis adaptation. In: Security Dialogue 42, 2, 143-160. https://doi.org/10.1177/ 0967010611399616

Walker, B.; Salt, D. (2006): Resilience Thinking: Sustaining Ecosystems and People in a Changing World. Washington DC.

Walker, B.; Salt, D. (2012): Resilience Practice: Building Capacity to Absorb Disturbance and Maintain Function. Washington DC.

Zhou, H.; Wang, J.; Wan, J.; Jia, H. (2010): Resilience to natural hazards: a geographic perspective. In: Natural Hazards 53, 1, 21-41. https://doi.org/10.1007/s11069-009-9407-y

Zhu, J.; Ruth, M. (2013): Exploring the resilience of industrial ecosystems. In: Journal of Environmental Management 122, 65-75. https://doi.org/10.1016/j.jenvman.2013.02.052

Zolli, A. (2013): Good-bye sustainability, hello resilience. In: Conservation $14,1,62-63$. 